\title{
Econometric Analysis of Effects of Nitrogenous Fertilizer Usage on Tomato Yield in Tokat, Turkey
}

\author{
Bilge Gözener $^{1 *}$, Ŏguz Parlakay² \\ ${ }^{I}$ Department of Agricultural Economics, Faculty of Agriculture, Gaziosmanpaşa University, 60240 Tokat, Turkey \\ ${ }^{2}$ Department of Agricultural Economics, Faculty of Agriculture, Mustafa Kemal University, 31060 Hatay, Turkey.
}

\begin{tabular}{l}
\hline A R T I C L E I N F O \\
Research Article \\
Received 31 January 2017 \\
Accepted 06 March 2017 \\
\hline
\end{tabular}

Keywords:

Econometric models

Economic optimum

Production functions

Quantitative relationship

Technical optimum

\begin{abstract}
A B S T R A C T
This study aims to investigate the effects of nitrogen fertilizer application on tomato yield by using econometric models. The data obtained by questionnaire from 53 farmers who produce tomatoes in Tokat province constitute the main material of the study. The Simple Random Sampling Method was used to determine the sample size with a $90 \%$ confidence interval and $10 \%$ margin of error. Nine models were tried to determine the best model to explain the effect of nitrogenous fertilizer usage in tomato cultivation. The data in the models were used to calculate the growers' optimal fertilizer amount of use (physical optimum and economical optimum values were calculated) and the results were compared to the ones suggested by the experts. As a result, through the statistical studies, quadratic model was found to be the most suitable one. It has been determined that tomato farmers use less $\left(10.54 \mathrm{~kg} \mathrm{da}^{-1}\right)$ or excess $\left(23.48 \mathrm{~kg} \mathrm{da}^{-1}\right) \mathrm{N}$ fertilizer than the level at which economic optimum is achieved.
\end{abstract}

\footnotetext{
*Corresponding Author:

E-mail: bilge.gozener@gop.edu.tr
}

DOI: https://doi.org/10.24925/turjaf.v5i4.441-444.1180

\section{Introduction}

There are many different input applications to increase the yield per unit area in agricultural production. Fertilization is one of the most important of these applications. According to many research, balanced fertilization provides more than $50 \%$ increase in yield under favorable conditions (Esengun et al., 1999; Bayramoğlu, 2010). Fertilizer, especially nitrogen, can cause serious environmental problems by infiltrating the groundwater and accumulating nitrates in plants that affect human health negatively (Guler, 2006). Unconscious usages of pesticides and fertilizers, improper tillage practices, residual risk, deterioration of soil's physical structure, the deterioration of loss and nutrient balance of organic matter and vitality, salinization, brings about important environmental issues such as desertification (Aksoy, 1999).

Various biological wastes with mineral and organic fertilizers are used improve the physical and chemical properties of soil in the world for many years and to increase the efficiency of materials. Turkey organic matter in the soil, except for limited maintenance is generally poor (Dinç et al., 2001).
Although the consumption of fertilizer, in a continuous increase per unit area in Turkey is currently well below the world average. In particular, grain yield per unit area and quantity of agricultural production is low (Eraslan et al., 2010). Therefore, determination of economic, ecological and technical (physical) quantity of fertilizer application is important.

The aim of this study is to evaluate and compare different quantitative models that explain the effects of nitrogen fertilizer application on tomato yield. In addition, the economic gains or losses of the farmers were determined using the selected model.

\section{Material and Methods}

The study constitutes the main material of the data obtained from 53 farmers who grow open field tomatoes in the central district of Tokat province. The data used in this study belong to the production period of 2012-2013 and were collected by questionnaire method. 
Nine quantitative models were tested to determine the relationship between the $\mathrm{N}$ fertilizer level and tomato yield.

A yield function is given below (Gujarati, 1995):

$$
Y=f\left(X_{i} / X_{j}\right)
$$

It is expressed that the Cobb-Douglas type function and the quadratic forms of the polynomial functions which are among the most commonly used as mathematical models to explain the fertilizer-yield relationship are the best explanatory ones (Rehber, 1989). It is assumed that $\mathrm{N}$ fertilizer costs are variable and other costs are fixed. In the study, technical and economical use of fertilizer levels was determined. When the first function is derived from the input (fertilizer) and equal to zero, the technical optimum level for fertilizer use can be determined. For the calculation of the level of fertilizer application at economic optimum, the $\mathrm{N}_{\text {op }}$ was calculated by setting the first derivative of the $\mathrm{N}$ fertilizer response curve equal to the ratio between the cost of fertilizer and the price of crop (Karkacier, 2001).

Economic optimum is: $d y / d x=P_{x} / P_{y}$,

Where, $\mathrm{P}_{\mathrm{x}}$ is the price of the input ( $\mathrm{N}$ fertilizer) per unit, and $\mathrm{P}_{\mathrm{y}}$ is the price of output (tomato) per unit. In the study, $\mathrm{N}$ fertilizer cost and tomato price are $1.19 \mathrm{~kg}^{-1} \$$ and $0.20 \mathrm{~kg} \mathrm{da}^{-1} \$$, respectively. The amount of fertilizer suggested by the Institute for Research fertilizer use is taken into account in determining the economic optimum.

Afterwards, economical optimum fertilizer dose was compared to the $( \pm \% 10)$ farmers' applications. The use of less than $10 \%$ of the optimum fertilizer dose is considered as a low use level and the use of more than $10 \%$ of the same dose usage is considered as a high use level. The farmers among these use the fertilizer in an economical level. Several quantitative studies made in this area in Turkey (Oruc and Gürler, 1995; Altintas and Karkacier, 2002; Demirtas and Yilmaz, 2003).

\section{Results and Discussion}

In the study, the values of the determination coefficient of the obtained models vary between 0.00 and 0.07. In all models, $\mathrm{R}^{2}$ values are low for other factors (high yielding seed, irrigation etc.) that affect crop yield.
Since the highest determinant coefficient is obtained by using the quadratic model, the economical optimum level for the use of nitrogen fertilizer is determined by the help of the quadratic model (Table 1). The signs of the estimated coefficients are in the expected direction and statistically significant at the $1 \%$ level.

Quadratic function is as follows:

$$
Y_{N}=3381-2,1 N-0,058 N^{2}
$$

The difference between the amount of fertilizer recommended by the experts and the amount of fertilizer used by the farmers was determined as $37.63 \mathrm{~kg} \mathrm{da}^{-1}$ at the technical optimum level and $10.02 \mathrm{~kg} \mathrm{da}^{-1}$ at the economic optimum level (Table 2).

In this study, it is determined that the farmers used a lower amount of nitrogenous fertilizer than suggested. In a research made in Kazova Plain in Tokat Province, the suggested amount of nitrogenous fertilizer usage is 35.00 $\mathrm{kg} \mathrm{da}^{-1}$ (Sahin et al., 2011), while in a study carried out by the research institute in the same province, this amount was found out to be $26.7 \mathrm{~kg} \mathrm{da}^{-1}$ (Noyan et al., 2002). In a study carried out in Tarsus district of Mersin province, Oktem and Bicer (1994) suggested the economic optimum level of nitrogenous fertilizer as $18.5 \mathrm{~kg} \mathrm{da}^{-1}$ for tomatoes; while Dagdeviren and Ozer (1996) have determined this level as $16 \mathrm{~kg}$ in a study in Harran plain, Bilgin (1996) as $12 \mathrm{~kg} \mathrm{da}^{-1}$ in Aegean region, Sefa et al. (1996) as $18 \mathrm{~kg} \mathrm{da}^{-1}$ in Bursa Province, Silva et al. (1997) as $20 \mathrm{~kg} \mathrm{da}^{-1}$, Kemble et al. (2000) as 17-20 kg da ${ }^{-1}$ in Alabama and Işı (2001) as $17.7 \mathrm{~kg} \mathrm{da}^{-1}$ in a study carried out in Konya Province. It is seen that the research results differ from the studies carried out in the region but they go around similar values with the suggested amounts in the other studies.

Approximately half of the surveyed farms (45.28\%) used more fertilizer than the amount recommended by the research institute and $11.32 \%$ used less fertilizer. It has been determined that some farmers lost $241.48 \mathrm{~kg} \mathrm{da}^{-1}$ in yield using $10.54 \mathrm{~kg} \mathrm{da}^{-1}$ less nitrogenous fertilizer than the recommended amount. On the other hand, The amount of nitrogenous fertilizer used more than the recommended level was determined as $25 \mathrm{~kg}$. The yield loss for these farms was calculated as $104.41 \mathrm{~kg} \mathrm{da}^{-1}$. The amount of loss of money for farms that used excess $\mathrm{N}$ fertilizer for tomato was $48.82 \$ \mathrm{da}^{-1}$ (Table 3). Money loss is out of the question in farmers that use less fertilizer.

Table 1 Functional relationships between nitrogenous fertilizer use and tomatoes yield

\begin{tabular}{l|lc}
\hline \multicolumn{1}{c|}{ Models } & \multicolumn{1}{c}{ Equations } & $\mathrm{R}^{2}$ \\
\hline Linear & $\mathrm{Y}=3443+6,4 \mathrm{~N}$ & $0.04(6)$ \\
Cubic & $\mathrm{Y}=4195-115 \mathrm{~N}+3,59 \mathrm{~N}^{2}-0,0319 \mathrm{~N}^{3}$ & $0.29(4)$ \\
Quadratic & $\mathrm{Y}=3381-2,1 \mathrm{~N}-0,058 \mathrm{~N}^{2}$ & $0.00(1)$ \\
Square root & $\mathrm{Y}=3153-1,7 \mathrm{~N}+3201 \sqrt{\mathrm{N}}$ & $0.07(7)$ \\
Exponential (log-log) & $\mathrm{Log} \mathrm{Y}=3,47+0,0106 \log \mathrm{N}$ & $0.01(2)$ \\
Semi-log (lin-log) & $\mathrm{Y}=3214+6 \log \mathrm{N}$ & $0.01(2)$ \\
Semi-log (log-lin) & $\mathrm{Log} \mathrm{Y}=3,51+0.00153 \mathrm{~N}$ & $0.15(3)$ \\
Cobb-Douglas & $\mathrm{Y}=3.42 \mathrm{~N}^{0.0106}$ & $0.01(2)$ \\
Reciprocal & $\mathrm{Y}=3560-60(1 / \mathrm{N})$ & $0.03(5)$ \\
\hline
\end{tabular}


Table 2 Comparison of the farmers' nitrogenous fertilizer usage and yield level with technical and economic optimum $\left(\mathrm{kg} \mathrm{da}^{-1}\right)$

\begin{tabular}{c|lll}
\hline Efficiency Kind & Farmers' usage (1) & Suggested amount by research institute (2) & Difference $(1-2)$ \\
\hline Technical Optimum & 18.10 & 55.73 & -37.63 \\
Economic Optimum & 16.68 & 26.70 & -10.02 \\
\hline
\end{tabular}

Table 3 Comparison of nitrogenous fertilizer usage levels in tomato production

\begin{tabular}{l|cc}
\hline \multicolumn{1}{c|}{ Variables } & $\begin{array}{c}\text { Less Nitrogen } \\
\text { Used Farms }\end{array}$ & $\begin{array}{c}\text { Excess Nitrogen } \\
\text { Used Farms }\end{array}$ \\
\hline Average Nitrogen Usage $\left(\mathrm{kg} \mathrm{da}^{-1}\right)(1)$ & 16.16 & 50.18 \\
Nitrogen Dose at Economic Optimum Level $\left(\mathrm{kg} \mathrm{da}^{-1}\right)(2)$ & 26.70 & 26.70 \\
Less $(-)$ and Excess $(+)$ Nitrogen Use $\left(\mathrm{kg} \mathrm{da}^{-1}\right)(3=1-2)$ & -10.54 & 23.48 \\
Average Yield $\left(\mathrm{kg} \mathrm{da}^{-1}\right)(4)$ & 3125.00 & 3261.87 \\
Yield at Economic Optimum Level $\left(\mathrm{kg} \mathrm{da}^{-1}\right)(5)$ & 3366.28 & 3366.28 \\
Loss of Yield $\left(\mathrm{kg} \mathrm{da}^{-1}\right)(6=5-4)$ & 241.48 & 104.41 \\
Loses of Money $\left(\$ \mathrm{da}^{-1}\right)\left(7=3 * \mathrm{P}_{\mathrm{N}}+6 * \mathrm{P}_{\mathrm{Y}}\right)$ & 35.76 & 48.82 \\
\hline
\end{tabular}

Note: $\mathrm{P}_{\mathrm{Y}}=\$ 0.20$ per kilo $\quad \mathrm{P}_{\mathrm{N}}=\$ 1.19$ per kilo

\section{Conclusions}

As a result, help of the quadratic model determines the economical optimum level for the use of nitrogen fertilizer. Therefore, the quadratic model is the most suitable model selected to explain the nitrogen fertilizer yield relationship in tomato production. It has also been determined that some tomato producers in the region use fertilizer at different levels as recommended. This leads to loss of yield and money. The use of excessive and unconscious fertilizers in agricultural production causes soil pollution and water pollution as well as damage to land. Therefore, producers should be aware of fertilization.

\section{References}

Aksoy U. 1999. Developments in Ecological Agriculture. Ecological Agriculture Organization Association Publications, Emre Publishing, İzmir.

Altintaş A, Karkacier O. 2002. Determination of economic level of fertilizer use for some crops in Kazova district of Tokat and the factors affecting fertilizer use. J. Agric. Fac., 19: 23-28. 2002. Available from: http://ziraatdergi.gop.edu.tr/Makaleler/ 295882850_23-28.pdf [Accessed: 22.02.2017].

Bayramoğlu Z. 2010. Agricultural productivity and importance. Selçuk University Journal of Agriculture and Food Sciences, 24 (3):52-61, ISSN:1309-0550.2010. Available from: http://stgbd. selcuk.edu.tr/stgbd/article/view/158/75 [Accessed: 22.02.2017],

Bilgin AE. 1996. KHGM, APK Head of Department Soil and Water Resources Research Branch Office, Soil and Water Resources Research Publication Summaries (1958-1995), Ankara.

Dağdeviren I. Özer MS. 1996. KHGM, APK Head of Department Soil and Water Resources Research Branch Office, Soil and Water Resources Research Publication Summaries (1958-1995), Ankara.

Demirtaş B. Yilmaz İ. 2003. Function analysis of different doses of fertilizer tomato production in greenhouse. Alatarım.2003, 2 (2):45-52. Available from: http://dergipark.ulakbim.gov.tr/alata/ article/viewFile/5000056670/5000053881\#page $=47$ Accessed: 22.02.2017].

Dikici H. 2007. The effect of different yield response models and fertilizer product prices on optimum nitrogen dosages. KSU Journal of Science and Engineering, 89 10(2).

Dinç U, Şenol S, Kapur S, Cangır C, Atalay I. 2001. Turkey Territories. Faculty of Agriculture, Cukurova University. Publication No:51, Adana.
Eraslan F, İnal A, Güneș A, Erdal İ, Coşkan A. 2010. The situation of chemical fertilizer production and consumption in Turkey, problems, solution offers and reforms. TMMOB Agriculture Engineers Chamber, Agriculture Engineering VII. Technical Congress. Ankara.

Esengün K, Sayılı M, Akça H. 1999. An evaluation of fertiliser, environment and organic farming. Proceedings of XXIXth Annual Meeting of ESNA, September 7-12, Wye-Kent-UK, Published by Austrian Research Centers, pp: 143-149. Available from: http://www.iaea.org/inis/collection/ NCLCollectionStore/_Public/34/018/34018377.pdf [Accessed: 22.02.2017 ].

Güler S. 2006. Developments on Fertilizer consumption of the world and Turkey. Ondokuz Mayis University Journal of Faculty of Agriculture. 2006. 21(2), 243-248. Samsun. http://dergi.omu.edu.tr/omuanajas/article/view/1009002399/100 9001743 [Accessed: 02.03.2017 ].

Gujarati DN. 1995. Basic Econometrics (Third Edition). McGrawHill Inc., New York. ISBN: 0-07-025214-9.

Işık Y. 2001. KHGM APK Head of Department Soil and Water Resources Research Branch Office, Soil and Water Research Yearbook, Ankara.

Kemble JM, Curtis L, Tyson TW. 2000. Guide to commercial staked tomato production in Alabama, ANR-1156, USA. Available from: http://www.aces.edu/pubs/docs/A/ANR1156/ANR-1156.pdf [Accessed: 22.02.2017.].

Karkacier O. 2001. Functional analyses on agricultural economy and quantitative findings to be withdrawn from these analyses. Gaziosmanpaşa University, Agriculture Faculty Publications: 49, Lecture Notes Series: 26, Tokat.

Noyan OF, Karaata H, Çağatay K, Demir M, Balcın M. 2002. The effects of nitrogenous fertilizer to be applied on pole tomato (lycopersicon esculentum mill) on yield and quality in TokatKazova conditions with fertigation method.

Oruç E, Gürler AZ. 1995. A research on supply and usage of chemical fertilizers in Tokat City Kazova District. Gaziosmanpaşa University Agriculture Faculty Journal, 12:5668. Available from: http://ziraatdergi.gop.edu.tr/Makaleler/ 1604298533_56-68.pdf [Accessed: 22.02.2017 ].

Oktem MO, Biçer Y. 1996. KHGM, APK Head of Department Soil and Water Resources Research Branch Office, Soil and Water Research Summaries, (1958-1995), Ankara.

Rehber E. 1989. Usage of cultivation functions in economic analysis of fertilizer tests. MPM Productivity Journal, 165-192, Ankara.

Sefa S, Oruç S, Gürün B. 1996. KHGM, APK Head of Department Soil and Water Resources Research Branch Office, Soil and Water Research Summaries (1958-1995), Ankara. 
Silva EC-DA, Alvarenga MAR, Carvalho JG-DE. 1997. Yield and blossom-end rot of the tomato plant (Lycopersicon esculentum Mill) pruned and grown under high planting density under the influence of nitrogen and potassium fertilization. Ciencia-eAgrotecnologia., 21: 3, 324-333.
Șahin S, Karaman MR, Ünlükara A, Geboloğlu N, Durukan A. 2011. Determination of suitable nitrogen dosage and plant water consumption with fertigation method in pole tomato cultivation at Tokat Kazova Province. Ege University Agriculture Faculty Journal, Special volume, 81-87, Available from: http://www.zfdergi.ege.edu.tr/edergiziraat/ozel_sayi1/kongrekitap14.03.2011.pdf [Accessed: 22.02.2017]. 